\title{
NONLINEAR SEISMIC ANALYSIS OF MASONRY INFILLED RC FRAME STRUCTURES
}

\author{
NELINEARNA SEIZMIČKA ANALIZA AB OKVIRNIH KONSTRUKCIJA SA ZIDNOM \\ ISPUNOM
}

\author{
Emin MAHMUD \\ Zdravko BONEV \\ Emad ABDULAHAD
}

\author{
PRETHODNO SAOPŠTENJE \\ PRELIMINARY REPORT \\ UDK:624.9.012.45.042.7:692.232.2 \\ doi:10.5937/GRMK1901017M
}

\section{INTRODUCTION}

Considering recent earthquakes happened during the last decade the seismic performance of reinforced concrete frames with masonry infill is a subject of great interest. Earthquakes in Chile (2010), Haiti (2010), New Zealand (2010) and Japan (2011 and 2018) can be quoted as examples providing about what is needed to be done in the future [1].

The behaviour of frames with masonry infill in seismic actions is associated with many specifics:1) both materials (masonry infill and reinforced concrete) have different deformation characteristics ductility ratios; 2) considering earthquake loading it is observed that masonry stiffness is slowly going down showing the tendency of growing up the cracks and damages. This process is found to be with reference to earthquake duration and earthquake intensity; 3) Compliance between masonry infill walls and reinforced concrete frame is generally dependent on interface surface considered as contact zones between both materials; 4) It is the purpose of the paper to carry out a proper

Dipl. Eng. Emin Mahmud, PhD Student, Department Reinforced Concrete Structures, Faculty of Structural Engineering, University of Architecture, Civil Engineering and Geodesy (UACEG), 1 Hristo Smirnenski Blvd., Sofia 1046, Bulgaria, e-mail: dipl.ing.eminmahmud@gmail.com Prof. Dr. Eng. Zdravko Bonev, Department Structural Mechanics, Faculty of Structural Engineering, University of Architecture, Civil Engineering and Geodesy (UACEG), 1 Hristo Smirnenski Blvd., Sofia 1046, Bulgaria, e-mail: zbp uacg@abv.bg

Assoc. Prof. Dr. Eng. Emad Abdulahad, Department Reinforced Concrete Structures, Faculty of Structural Engineering, University of Architecture, Civil Engineering and Geodesy (UACEG), 1 Hristo Smirnenski Blvd., Sofia 1046, Bulgaria, e-mail: georgosing@gmail.com investigation and develop a procedure for fast evaluationof masonry infills influence on seismic demand and on overall seismic performance of the structure

The overall model of a framed masonry structure consists of two substructures - reinforced concrete frame and masonry (as diagonal element) introduced by its specific parameters using an appropriate procedure based on laboratory data. Inelastic deformation of both substructures implies that overall behaviour of framed masonry is specified as nonlinear and structure should be studied on the basis on nonlinear analysis.

In this paper an analysis has been carried out to evaluate the influence of masonry infill on the seismic performance of one day single storey plane reinforced concrete frame structure. Three models for numerical analyses are performed considering the reinforced concrete frame. At first, response spectrum method is applied to determine the design of seismic load and corresponding action effects according to the National code and European provisions. This model is denoted as model M1. After determination of design seismic loads, the design action effects are determined through linear and response spectrum analyses. After this step columns and girder of the frame are designed in conformity with European standards and European detailing rules. In the next second model M2 the contribution of masonry infill is not taken into consideration because masonry infill is not in use. This model is capable to develop inelastic deformations and should be studied based on nonlinear analysis. The third model M3 contains masonry infill and its contribution to the frame stiffness is considered using equivalent diagonal strut element (corner to corner model). To model the strut diagonal in SAP2000 v20 [2] multi-linear plastic link elements are used. 


\section{EQUIVALENT DIAGONAL COMPRESSION STRUT}

Aiming to overcome the complexity of the numerical models and optimize the procedures known as much time consuming it is a good idea to use macro elements to model masonry infill. The most elementary one is the diagonal strut element which is capable of simulating the infill wall resistance to lateral seismic forces. The basic idea of using strut models is to determine the global effect of masonry infill on the global behaviour of RC frame - infill structure. Analytical and experimental studies carried out by Polyakov [3], [4] show properly formation of compression diagonal strut. The basic problem is to identify physical properties of this element.

At first the concept is developed assuming only one diagonal strut connecting upper and lower edges of the masonry panel by following compression diagonal geometry. In order to generalize the model including cyclic behaviour strut elements are placed in each diagonal direction of masonry panel. Having in mind that tensile stress is small enough compared to compression ones it is reasonable to accept that the level of tensile stress is negligibly small and can be assumed to be zero. This means that only compression diagonal element resists to horizontal seismic force. Two varieties for diagonal struts can be used - concentric and eccentric [1], [5], [6] see Fig. 1.

During the last two decades it becomes clear that the model containing the only one element is incapable to reproduce the complex seismic performance of masonry infill. A number of researchers (Chrysostomou et el. [7], [8], Crisafulli [9] El-Dakhkhni et al. [10], [11], [12], Crisafulli and Carr [13], Rodrigues et al. [14], [15], Mihaleva [6] et al.) modified firstly proposed single diagonal using few diagonals gathered in one model. As a result of this the contact zones and interface surfaces are more precisely modelled especially opening the tensile surfaces located at the edge. Thus, new complex element accounts for larger tensile released stress zone. It is capable of modelling shear strength greater than the corresponding shear strength of surrounding framing elements. It is worth to mention the conclusion that the complex element is more accurate considering the edge contact zones, and the greatest advantage of a single diagonal model is its simplicity.
A number of researchers propose various relationships to determine the equivalent width of the strut compression diagonal. According to Holmes [16] the width of the equivalent compression diagonal $\left(b_{\text {wiinf }}\right)$ is $33 \%$ of the diagonal length of the infill panel. Paulay and Priestley [17] recommended the equivalent strut width to be specified as $25 \%$ of the panel diagonal. They concluded that the bandwidth does not depend on the lateral stiffness of the framing system. Abdelkareem, Cathrin et el. [18], [19] considered various approaches for determination of $b_{\text {winf }}$. The authors concluded that the strut width ranges between $1 / 10$ to $1 / 3$ of the geometric length of masonry panel [6], [18].

There are not exact provisions in Eurocode 8 [20] about the equivalent compression strut width. In FEMA306 [21] buinf the model of masonry infill proposed is expressed by the following quantities:

$$
\begin{gathered}
\lambda_{1}=\sqrt[4]{\frac{E_{\text {winf }} t_{\text {winf }} \sin (2 . \theta)}{4 . E_{c m} I_{c} h_{\text {winf }}}} \\
b_{\text {winf }}=\frac{0,175 r_{\text {winf }}}{\left(\lambda_{1} \cdot l_{c}\right)^{0,4}}
\end{gathered}
$$

where:

$b_{\text {wint }}-$ equivalent diagonal strut;

$r_{\text {winf }}$ - diagonal length of infill panel;

$\theta-\quad$ angle, whose tangent is the infill height-tolength aspect ratio;

$h_{\text {winf }}$ - height of infill panel;

$t_{\text {winf }}-$ thickness of infill panel and equivalent strut;

$E_{\text {winf }}$ - modulus of elasticity of infill material;

$\lambda_{1}-$ function of the relative panel-to-framestiffness parameter;

$l_{c}-\quad$ column height between centrelines of beams;

$I_{c}-$ moment of inertia of column;

$E_{c m}-$ modulus of elasticity of frame material

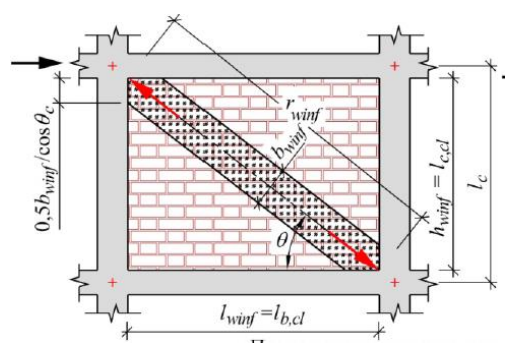

Corner to corner model

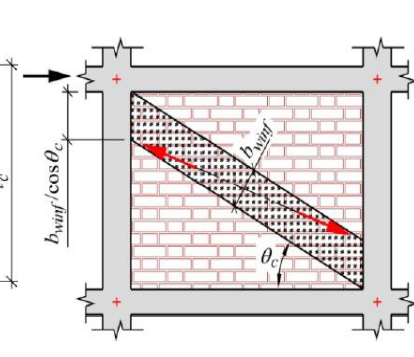

Column-to-column model

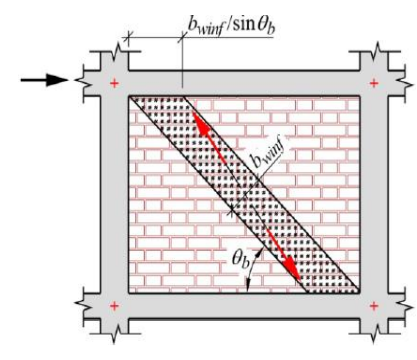

Beam-to-beam model

Fig. 1. Strip defined diagonal containing a single equivalent strut element [5] 


\section{SHEAR CAPACITY OF MASONRY INFILL}

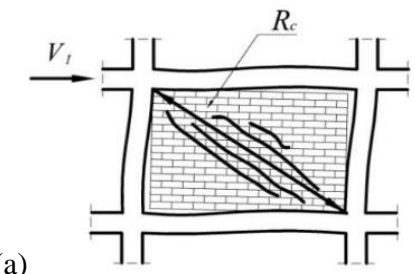

(b)

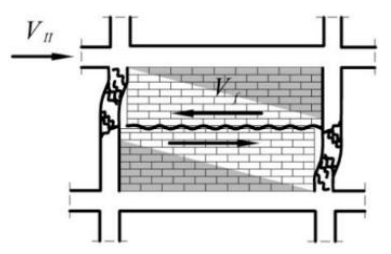

Fig. 2. Most frequently considered failure modes of masonry infill: failure of compression diagonal (a) and horizontal sliding of masonry panel (b) [22]

Mainly two failure modes of masonry infill panel are dominant when structures are subjected to seismic action. First one is characterized by failure of compression diagonal (Fig. 2a). Second failure mode is related to horizontal shear (sliding mode) of the masonry panel (Fig. 2b) [22]. Horizontal capacity of the masonry panel is determined on the basis of horizontal resistance of masonry panel, based on horizontal capacity of the horizontal joints $F_{\text {wint,hor,st, which is accepted to be equal }}$ to initial strength of masonry in shear assuming zero compression strength $f_{v o d}$. For masonry infill with thickness $t_{\text {winf }}$ and length / winf horizontal capacity of the joints is determined using expression (3). Equivalent diagonal compression capacity is determined using formula (4), as well,

$$
\begin{gathered}
F_{\text {winf }, \text { hor }, s f}=f_{v 0 d} t_{\text {winf }} l_{\text {winf }} \\
F_{\text {winf }, \text { hor }, c f}=f_{d} t_{\text {winf }} b_{\text {winf }} \cdot \cos \theta
\end{gathered}
$$

where:

$F_{\text {winf,hor }}$ horizontal capacity of the masonry panel

$f_{\text {vod }}$ - design initial strength in shear of masonry assuming zero compressive stress;

$f_{d}-\quad$ design strength of masonry;

$b_{\text {winf }}-\quad$ equivalent diagonal strut;

$t_{\text {winf }}-\quad$ thickness of infill panel and equivalent strut;

Iwinf - length of infill panel;

$\theta-\quad$ angle, whose tangent is the infill height-tolength aspect ratio;

\section{ANALYSIS OF FRAMES CONTAINING INFILL MASONRY}

Single storey one bay reinforced concrete frame with brick masonry panel is studied. Cross section dimensions are given as follows: columns $400 / 400 \mathrm{~mm}$, beam 300/400 $\mathrm{mm}$ and thickness of masonry infill -250 mm (see Fig. 3, Fig. 4, Tab. 1 and Tab. 2). The frame is loaded using distributed trapezoidal load. Permanent uniformly distributed loads including all loads of this type is $g_{k}=45 \mathrm{kN} / \mathrm{m}^{\prime}$, service loads are assumed $q_{\mathrm{k}}=15 \mathrm{kN} / \mathrm{m}^{\prime}$.

The seismic design of the frame is carried out aiming the frame to withstand the design earthquake for seismic zone Blagoevgrad (Bulgaria), characterized by reference ground acceleration for free field $\mathrm{a}_{\mathrm{g} R}=0,32 . \mathrm{g}$, importance factor $\gamma_{1}=1,00 n$ coefficient of behaviour $q=2,00$ (it is assumed that the forces as action effects coming from the design earthquake, are reliable). Ground type B and response spectrum of Type 1 according to the National code [20] are also used. In addition, nationally determined parameters from the Bulgarian National Annex [23] should be mentioned as important for design seismic action definition.

To reach the paper purposes three static analyses are performed. First analysis is linear, the other two analyses are nonlinear. In first nonlinear analysis masonry infill is not accounted for. In the next nonlinear analysis, the masonry infill is taken into considerations. Seismic analyses are performed using SAP2000 v20 computer software [2]. Three different numerical models are applied. Seismic action is assumed as single component (horizontal) and located within the frame plane.

\subsection{Numerical model M1}

The numerical model M1 is used to carry out the first step of the analysis scheduled - seismic design procedure. To do this response spectrum analysis is applied in combination with linear analysis. At this stage masonry infill is not accounted for. The output of this step is that the structure is designed and detailed according to Eurocode 1998-1 [20], [23] to withstand the design earthquake. The reinforcement obtained as a result of the design procedure application is provided in Table 1:

Tab. 1. The quantity of reinforcement used in columns and beam

\begin{tabular}{|c|c|c|c|c|c|c|}
\hline member & Concrete & Reinforcing steel & Cross section & Longitudinal reinforcement & \multicolumn{2}{|c|}{$\begin{array}{c}\text { Transverse } \\
\text { reinforcement }\end{array}$} \\
\hline beam & C25/30 & B500C & $300 \times 400 \mathrm{~mm}$ & $4 \varnothing 16$ (top) and $4 \varnothing 14$ (bottom) & $\varnothing 8 / 100$ & $\varnothing 8 / 200$ \\
\hline columns & $\mathrm{C} 25 / 30$ & B500B & $400 \times 400 \mathrm{~mm}$ & $8 \varnothing 16$ & $\varnothing 8 / 125$ & $\varnothing 8 / 250$ \\
\hline
\end{tabular}




\subsection{Numerical model M2}

In Numerical model M2 a non-linear static analysis is performed. This model fails to include masonry infill into the calculations. Analysis is carried out assuming permanent vertical loading and lateral load increasing stepwise. Columns and girder are connected using rigid rotational links in their joints. Plastic deformations are considered by implementation of plastic hinges into the numerical model M2 close to beam-to-column joints, see Fig. 3.

Specific data for plastic hinges is prepared including the reinforcement available. Plastic hinges are modelled by using inelastic rotation spring interconnecting two neighbouring cross sections. Constitutive material relationship for rotational spring of the type "bending moment - axial force - relative rotation of the cross sections" is used. Both cross sections are interconnected with the rotational spring. The bending moment in rotational spring is dependent on the axial force more essentially in the columns, $\left(M_{3}-P\right)$.

\subsection{Numerical model M3}

To define inelastic cyclic behaviour of masonry, infill the Hysteretic Pivot model [2] (Fig. 5a.) is used. An inelastic static analysis is performed over the $\mathrm{RC}$ frame using the formulation M3, see Fig. 4. The proposed equivalent strut model is employed and illustrated in Fig. 4. Models M2 (see Fig. 3) and model M3 are similar and convenient to be numerically compared, but the only difference is that $M 3$ includes the contribution of the masonry infill through the strut diagonal member. In SAP2000 v20 [2] the equivalent strut diagonal is modelled by multi-linear plastic link element. This model has large flexibility in modelling structures developing unsymmetrical hysteretic loops under the action of axial force in compression-tension. Hysteretic loops are numerically controlled through the parameters $\alpha_{1}, \alpha_{2}, \beta_{1} u$ $\beta_{2}$. The Hysteretic Pivot model has specific and simplified rules when applied to tensile equivalent strut members (Fig. 5b.).

Hysteretic rules are load dependent and numerically controlled using the parameters $\alpha_{1}, \alpha_{2}, \beta_{1} u \beta_{2}$. The use of Hysteretic Pivot model has the advantage to offer simplified rules to be applied to equivalent diagonal strut (Fig. 5b.). In this case, since the tensile strength of masonry infill is not considered, the parameters $\alpha_{1}$ and $\beta_{1}$ are generated both to be zero [24]. The hysteretic model specified herein has another advantage generates always positive stiffness. In dynamic analysis the use of negative or zero tangential stiffness may influence the stability of the numerical solution.

Experimental investigations show that for frames containing masonry infill panels the change of the sign of seismic action does not lead to increase of the stiffness. It is established that the $\beta_{2}$ is also zero. Hysteretic loop controlled its area through the parameter $\alpha_{2}$. The value of 0.25 is taken the following reference [24].

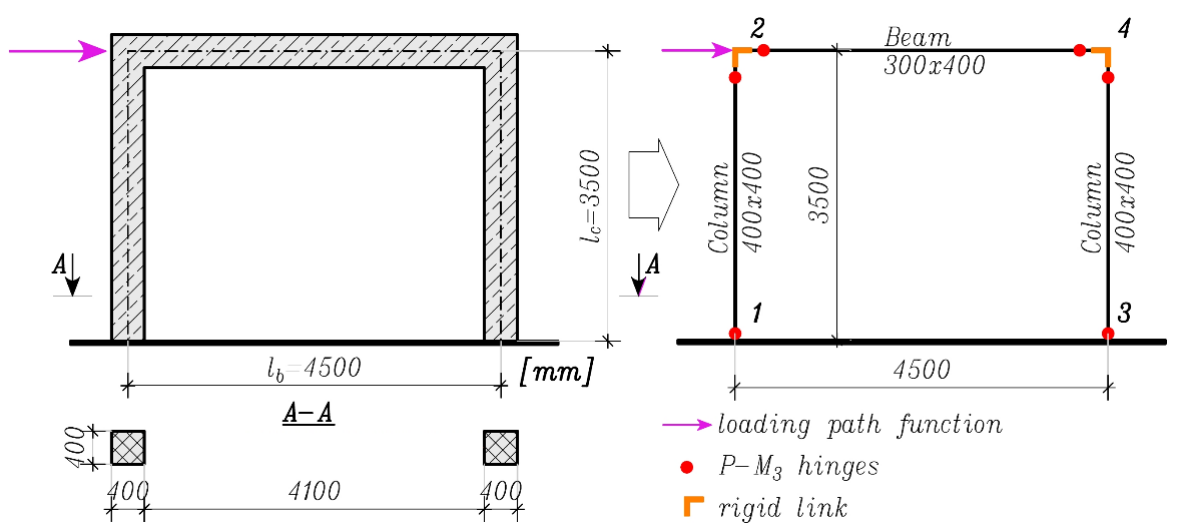

Fig. 3. Structure model based on formulation M2

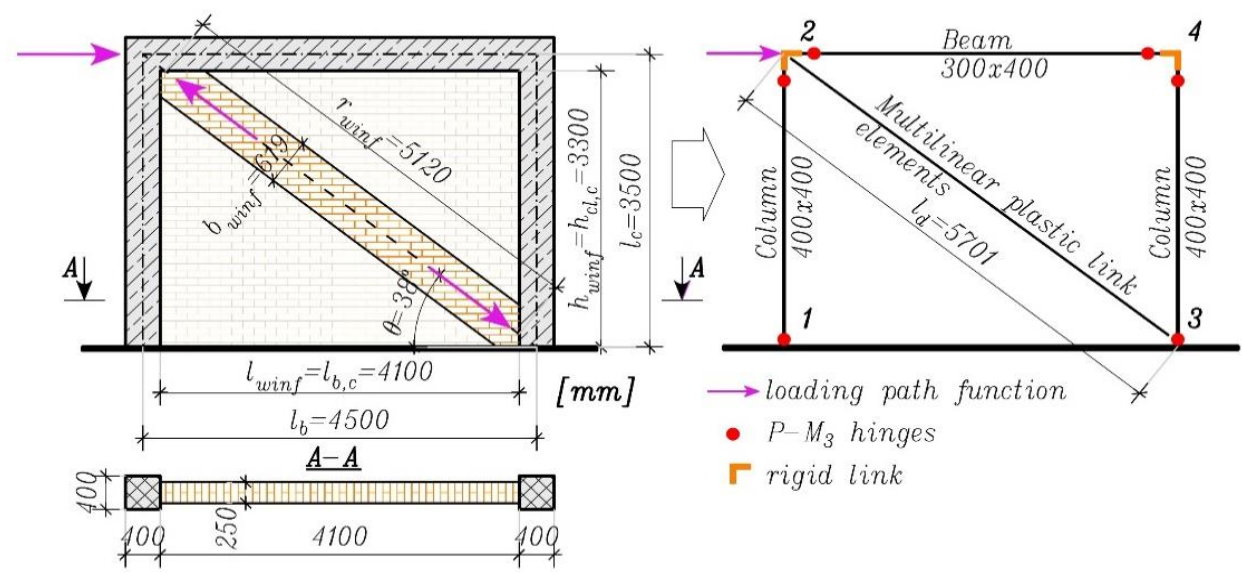

Fig. 4. Structure model based on formulation M3 


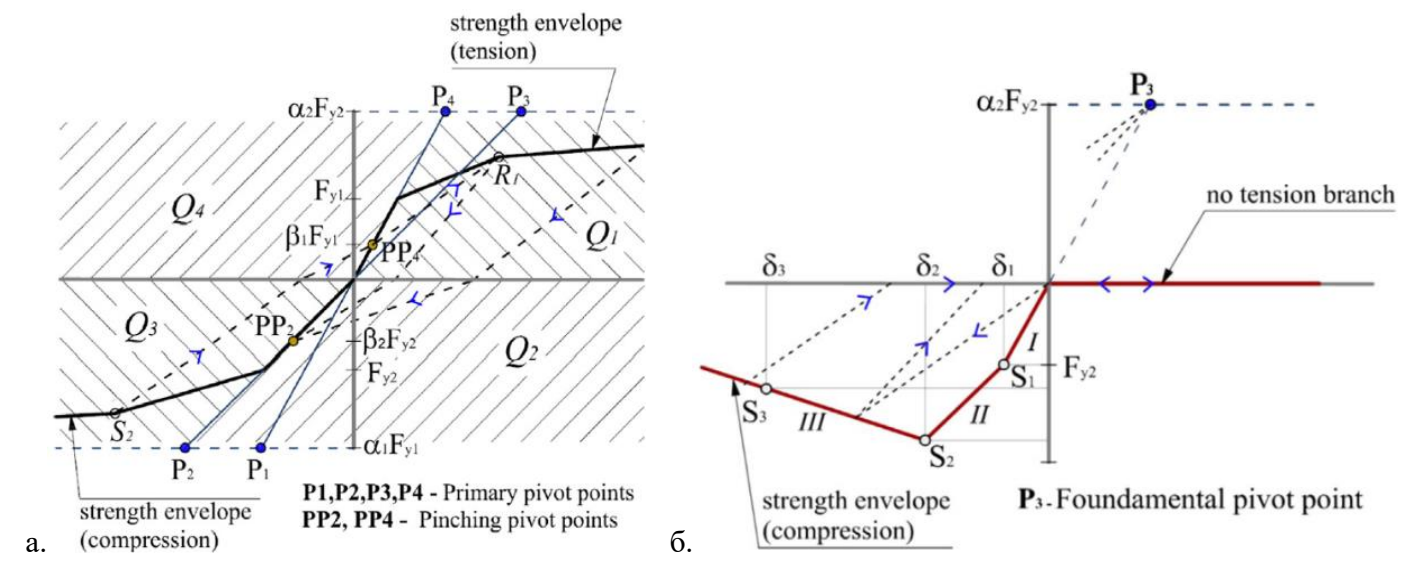

Fig. 5. Hysteretic Pivot model: a) unsymmetrical hysteretic loop and b) equivalent compressive diagonal [24].

Due to define and compose equivalent diagonal strut model, characteristics of masonry are determined in conformity with European standard Eurocode 1996-1-1 [25], [26] and Eurocode 1998-1 [20] for seismic resistant building structures. A block structure for masonry infill of Group 2 is used and mortar containing lightweight additive materials having volume weight $\rho_{d} \leq 800 \mathrm{~kg} / \mathrm{m}^{3}$. Characteristic strength of masonry $f_{k}$ is

$$
f_{k}=K f_{b}^{0,70} f_{m}^{0,30}=0,25 \cdot 10^{0,70} \cdot 5^{0,30}=2,03 \mathrm{MPa}
$$

The design strength of masonry $f_{d}$ with blocks of category I and prescribed dimensions are given as:

$$
f_{d}=\frac{f_{k}}{\gamma_{M}}=\frac{2,03}{2,00}=1,01 M P a
$$

The characteristic initial strength in shear of masonry assuming zero compressive stress and made of clay blocks and mortar with light additive materials is $f_{v o k}=0,15 \mathrm{MPa}$ and the design strength is $f_{v o d}=0,075 \mathrm{MPa}$.

The durable secant modulus of masonry is:

$$
E_{\text {long term }}=\frac{1000 \cdot f_{k}}{1+\phi_{\infty}}=\frac{1000 \cdot 2,03}{1+1,10}=967 \mathrm{MPa}
$$

The width within the model of equivalent diagonal strut in compression is derived after using equations (1) and (2):

$$
\begin{aligned}
& \lambda_{1}=\sqrt[4]{\frac{E_{\text {winf }} t_{\text {winf }} \sin (2 . \theta)}{4 . E_{\text {cm }} I_{c} h_{\text {winf }}}}= \\
& =\sqrt[4]{\frac{967 \cdot 250 \cdot \sin 76}{4.31000 \cdot \frac{400 \cdot 400^{3}}{12} \cdot 3300}}=7,1992 \cdot 10^{-4} \mathrm{~mm}^{-1} \\
& b_{\text {winf }}=\frac{0,175 r_{\text {winf }}}{\left(\lambda_{1} \cdot l_{c}\right)^{0,4}}=\frac{0,175.5120}{\left(7,1992.10^{-4} \cdot 3500\right)^{0,4}}=619 \mathrm{~mm}
\end{aligned}
$$

\begin{tabular}{|c|c|c|c|c|c|c|c|}
\hline$l_{\text {winf }}$ & $t_{\text {winf }}$ & $\theta$ & $f_{v 0 d}$ & $f_{d}$ & $l_{d}$ & $\boldsymbol{b}_{\text {winf }}$ & $F_{\text {winf,hor,cf }}$ \\
\hline $\mathrm{mm}$ & $\mathrm{mm}$ & $o$ & $M P a$ & $M P a$ & $\mathrm{~mm}$ & $\mathrm{~mm}$ & $k N$ \\
\hline 4100 & 250 & 38 & 0,075 & 1,02 & 5701 & 619 & 123,80 \\
\hline \multicolumn{2}{|c|}{$F_{\text {winf,hor,sf }}$} & $V_{y}$ & $V_{m}$ & $V_{p}$ & $\delta_{1}$ & $\delta_{2}$ & $\delta_{3}$ \\
\hline \multicolumn{2}{|c|}{$k N$} & $k N$ & $k N$ & $k N$ & $\mathrm{~mm}$ & $\mathrm{~mm}$ & $\mathrm{~mm}$ \\
\hline \multicolumn{2}{|c|}{76,90} & 57,7 & 76,9 & 15,4 & $-10,9$ & $-14,5$ & $-25,3$ \\
\hline
\end{tabular}

The minimum shear capacity basing on both possible failure mechanisms, is:

$$
\begin{aligned}
& V_{m}=F_{\text {winf }, \text { hor }}=\min \left\{\begin{array}{l}
F_{\text {winf }, \text { hor }, s f} \\
F_{\text {winf }, \text { hor }, \text { ff }}
\end{array}=\right. \\
& =\min \left\{\begin{array}{l}
0,075 \cdot 250 \cdot 4100 \\
1,015 \cdot 250 \cdot 619 \cdot \cos 38^{\circ}
\end{array}=\min \left\{\begin{array}{l}
76,9 \\
123,8
\end{array}=76,9 \mathrm{kN}\right.\right.
\end{aligned}
$$

Tab. 2. Parameters defining Hysteretic Pivot model 
The point S2 in Hysteretic Pivot model for equivalent diagonal replacing strut (Fig. 5b.) is defined when both maximum capacity of masonry panel $V_{m}$ and displacement $\delta_{2}$ are reached. The point $\mathrm{S} 1$ is defined when $75 \%$ of $V_{m} \quad\left(V_{y}=0,75 . V_{m}\right)$ is reached and displacement becomes $\delta_{1}$. PointS3 is defined when the peak of the strength drop to $20 \%$ of $V_{m}\left(V_{p}=0,20 . V_{m}\right)$ is reached and displacement becomes $\delta_{3}$.

The displacements $\delta_{1}, \delta_{2}, \delta_{3}$ are determined based on normal strains $\varepsilon i$ pointed out in [27]. Table 2 contains defining parameters of Hysteretic Pivot model.

\section{ANALYSIS OF THE RESULTS ON OUTPUT}

Inelastic static performance of framed masonry is presented by means of the curve "base shear force roof horizontal displacement". Numerical models M2 and M3 are used to evaluate the contribution of masonry infill on the seismic demands for roof displacements. The results can be seen in Fig. 6 which represents in graphical format the curves "base shear force horizontal displacement at the top". Both curves are obtained computationally using computer software. The curves are also called "capacity curves". Capacity curves for structure without masonry infill are denoted as violet lines, whereas the same curves for structure with masonry infill are denoted with red dashed lines.

In general, the horizontal base shear force in case of added diagonal strut is formed as a sum of the frame base shear and horizontal projection of the diagonal force in compression. External loading is shown in Fig. 6 coloured in pink. The resistance force has two counterparts - first is coming from the reinforced concrete frame, second appears to be a result of added masonry infill represented in the computer model as diagonal strut. Both forces are internal forces, see Fig. 6 . Internal forces must equilibrate the external forces, see Fig. 6. Thus, the frame resists to progressively increasing external static loads through internal resisting forces. Furthermore, internal forces depend on displacements and this relationship is as a rule implicit and nonlinear. That is why the solution of the nonlinear static problem is found using iterations. After each iteration internal forces need to be revaluated and rest between external and internal forces is getting smaller. If external and internal forces become equal, equilibrium is reached. In the descending branch of the capacity curve internal force is going down. This means that internal force is no capable of resisting to increasing external forces any further. If equilibrium cannot happen any longer, the process of failure occurs. The initial stage of loading history is characterized with the fact that the system behaves itself linearly. After the development of inelastic deformations, the capacity curve properly expressed nonlinear behaviour (Fig. 6). Masonry infill contributes towards reduction of displacement demand. On the other hand the capacity in lateral direction is increased. When further stages of loading history are considered, it is observed, that the masonry infill is participated more actively (Fig. 6), in formation of the lateral resistance. Having this in mind, the maximum shear force at the base is reached the amount of 191,50 $\mathrm{kN}$ as observed (point E).

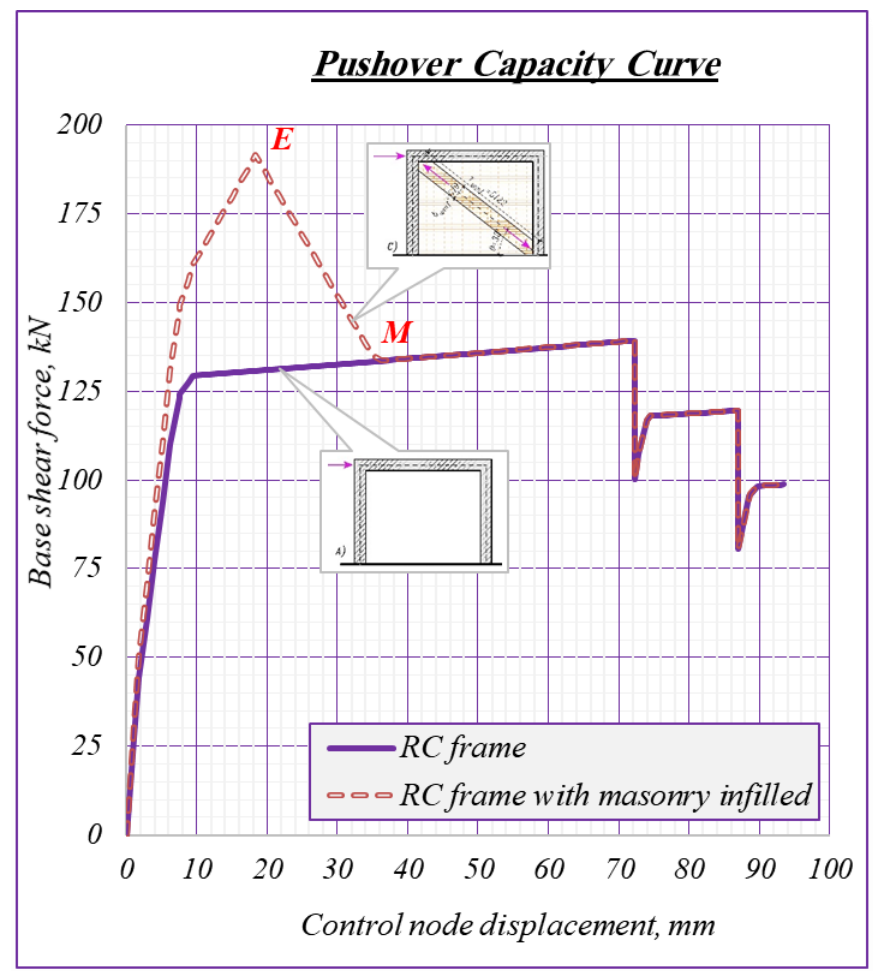

Fig. 6. Capacity curves of reinforced concrete frame (a) with (red dotted line) and without (violet line) masonry infill 
After reaching point $E$, intensive crack initiation, capacity degradation and stiffness of the masonry are noticed. Its resistance essentially drops down. When base shear force is $133,60 \mathrm{kN}$ (at about $70 \%$ of shear capacity), masonry infill is incapable of resisting to horizontal loads anymore. Point M (Fig. 6) is intersection point for two capacity curves. At point $M$ the masonry infill is fractured and damaged. For displacement demands greater than $0.036 \mathrm{~m}$ both capacity curves (frame with masonry infill and frame without infill) completely fit each other. Dissipated seismic energy for frame with masonry infill is $23 \%$ greater than dissipated energy for frame without masonry infill.

In references [20], [28] the procedure of evaluation of design seismic performance is considered and discussed. The N2-method is focused on determination of the performance point. It is found as intersection point between capacity spectrum and design demand spectrum (Fig. 7). The comparison between calculated seismic displacement demand $S_{d}$ and maximum admissible level of structural performance is a good opportunity to see whether the structure is in conformity with new generation of code provisions or not.

Fig. 7 illustrates the application of N2 method [29] to find out the displacement seismic demand. The design seismic action is presented using "design demand spectrum" plotted in $S_{a}-S_{d}$ format (accelerationdisplacement format). Spectral acceleration can physically be treated as a "force per unit mass". Thus, the spectral acceleration $S_{a}$-can be identified as external quasi-static force used to load the structure in compliance with the design seismic action. The capacity curve provides the resistance spectrum and the equality between external and internal forces means that both forces are in equilibrium. Obviously, this happen when displacement has the demand value called also "target displacement". It is evident from Fig. 7 that at intersection points $P_{1}$ and $P_{2}$ structural performance is ductile and collapse is not reached.

The influence of masonry infill on design seismic performance of the frame is illustrated in Fig. 6 and Fig. 7. The evaluation is based on comparison of the position of performance point of both capacity spectra - frame with masonry infill (red dotted line) and without infill (violet line). In the first case (red dotted line) design displacement demand is 2,3 times smaller than the result of violet line, where no masonry infill is considered.

\section{CONCLUSIONS}

Nonlinear static analysis of a RC frame is performed. Two well known cases from the practice are studied - the frame with masonry infill (case 1) and the frame without masonry infill (case 2). The analysis is carried out assuming constant vertical load and horizontal load increasing stepwise. As a result, two capacity curves are presented (for case 1 and case 2). Design seismic demands are evaluated for both cases. The benefit of using masonry infill is clarified and explained.

Masonry infill on one hand increases static lateral stiffness of overall structure and resists netter to seismic loads, on the other hand base shear capacity is increased. After reaching the greatest horizontal static level of loading the process of intensive cracking is observed, stiffness degradation occurs and capacity steeper goes down. The structure has no capability to resist external horizontal loads.

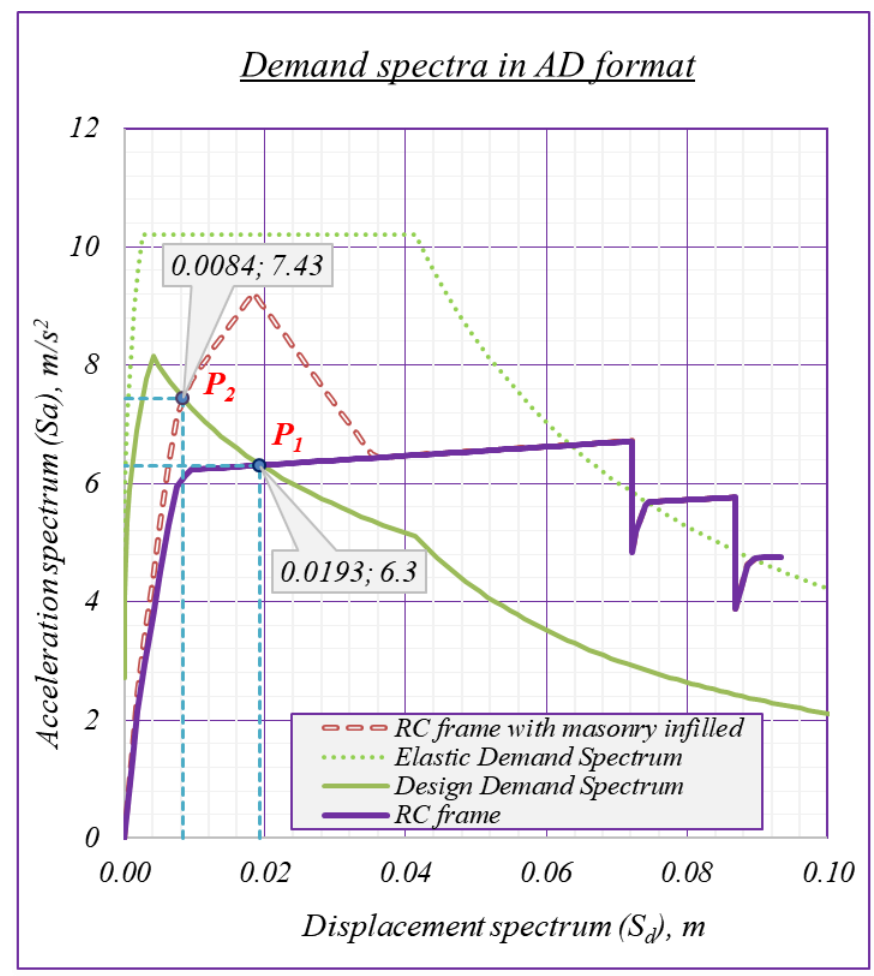

Fig. 7. Determination of performance point and displacement demands for structure without masonry and with masonry 
At the beginning of the loading process the linear behaviour is dominant in the performance. Initial stiffness of the frame containing masonry infill $K_{0}$ is $20 \%$ greater compared to initial stiffness $K_{0, f}$ of the frame without masonry infill. After reaching limit value of the horizontal load starts intensive cracking and stiffness degradation. As a result of this the capacity of masonry infill in carrying horizontal loads is drastically decreased. Looking at capacity curves it can be properly seen that after ending this process contribution of masonry disappears and both curves are the same.

\section{REFERENCES}

[1] Tabeshpour, M. R., A. Azad, \& A. A. Golafshani, "Seismic Behavior and Retrofit of Infilled Frames," in Earthquake-Resistant Structures - Design, Assessment and Rehabilitation, Prof. Abbas Moustafa, Ed. 2012, pp. 279-306.

[2] "SAP2000," 2018. [Online]. Available: http://docs.csiamerica.com/manuals/sap2000/.

[3] Polyakov, S. V., "Masonry on Framed Building; An Investigation into the Strength and Stiffness of Masonry Infillings (Translation into English by G. L. Cairns)," Gos. Izd. po Stroit. I Arkhitekture, 1956.

[4] Polyakov, S. V., "On the interaction between masonry filler walls and enclosing frame when loading in the plane of the wall," Transl. Earthq. Eng. Earthq. Eng. Res. Inst., pp. 36-42, 1960.

[5] Кърджиев, В., Изследване поведението на неконструктивни елементи при сеизмични въздействия. София: УАСГ, 2016.

[6] Михалева, Д., Изследвания върху сеизмичното поведение на обрамчени зидарии. Варна: Дисертационен труд, 2011.

[7] Chrysostomou, C. Z., "Effects of degrading infill walls on the nonlinear seismic response of twodimensional steel frames," Dissertation, Cornell University, 1991.

[8] Chrysostomou, C. Z., P. Gergely, \& J. F. Abel, "A six-strut model for nonlinear dynamic analysis of steel infilled frames," Int. J. Struct. Stab. Dyn., vol. 2, no. 3, pp. 335-353, 2002.

[9] Crisafulli, F., "Seismic behaviour of reinforced concrete structures with masonry infills," Ph.D. thesis, Univ. of Canterbury, Christchurch, New Zealand, 1997.

[10] El-Dakhakhni, W. W., M. Elgaaly, \& A. A. Hamid, "Three-strut model for concrete masonry-infilled frames," J. Struct. Eng., vol. 129, no. 2, pp. 177185, 2003.

[11] El-Dakhakhni, W. W., M. Elgaaly, \& A. A. Hamid, "Finite Element Modeling of Concrete MasonryInfilled Steel Frame," 9th Can. Mason. Symp., 2001.

[12] El-Dakhakhni, W. W., "Experimental and Analytical Seismic Evaluation of Concrete Masonry-Infilled Steel Frames Retrofitted using GFRP Laminates," Ph.D. thesis, Drexel University, 2002.

[13] Crisafulli, F. J. \& A. J. Carr, "Proposed macromodel for the analysis of infilled frame structures," Bull. New Zeal. Soc. Earthq. Eng., vol. 40, no. 2, pp. 69-77, 2007.
Dissipated seismic energy of the frame is increased $23 \%$ due to masonry infill considering frame masonry. It is numerically proven in the present paper that the main benefit of using masonry infill in combination with reinforced concrete frame is the displacement seismic demand reduction and corresponding increased capacity of horizontal seismic resistance. Due to increase the dissipated seismic energy, it is necessary to improve the property of masonry, which is non-ductile material. This improvement can be achieved by reinforced masonry, using friction dampers and others.

[14] Furtado, A., H. Rodrigues, \& A. Arêde, "Modelling of masonry infill walls participation in the seismic behaviour of RC buildings using OpenSees," Int. J. Adv. Struct. Eng., vol. 7, no. 2, 2015.

[15] Rodrigues, H., H. Varum, \& A. Costa, "Simplified macro-model for infill masonry panels," J. Earthq. Eng., vol. 14, no. 3, pp. 390-416, 2010.

[16] Holmes, M., "Steel Frames with Brickwork and Concrete Infilling," Proc. Inst. Civ. Eng., vol. 19, no. 6501, pp. 473-478, 1961.

[17] Pauley, T. \& M. J. N. Priestley, Seismic design of reinforced concrete and masonry buildings. New York, 1992.

[18] Abdelkareem, K., F. A. Sayed, M. Ahmed, \& N. ALMekhlafy, "Equivalent Strut Width for Modeling R.C. infilled Frames," J. Eng. Sci., vol. 41, no. 3, pp. 851-866, 2013.

[19] Catherin, J. M., B. R. Jayalekshmi, \& K. Venkataramana, "Modeling of Masonry infills - A review," Am. J. Eng. Res., pp. 59-63, 2013.

[20] Eurocode 8: Design of structures for earthquake resistance (EN 1998). Part 1: General rules, seismic actions and rules for buildings (EN 19981). European Committee for Standardization (CEN), 2006.

[21] FEMA 306, "Evaluation of earthquake damaged concrete and masonry wall buildings, basic procedures manual." ATC-43, FEMA 306, Applied Technology Council, Calif., 1999.

[22] Таскова, А., "Сеизмична оценка и усилване на съществуващи сгради със стоманобетонна конструкция," Дисертационен труд, 2016.

[23] Eurocode 8: Design of structures for earthquake resistance - Part 1: General rules, seismic actions and rules for buildings - National annex to BDS EN 1998-1:2005, 2012.

[24] Cavaleri, L. \& F. Trapani, "Cyclic response of masonry infilled RC frames: Experimental results and simplified modelling," Soil Dyn. Earthq. Eng., vol. 65, no. November 2017, pp. 224-242, 2014.

[25] Eurocode 6: Design of masonry structures (EN 1996). Part 1-1: General - Rules for reinforced and unreinforced masonry structures (EN 1996-1-1), 2005

[26] Eurocode 6: Design of masonry structures - Part 1 1: General rules for reinforced and unreinforced masonry structures - National annex to BDS EN 1996-1-1:2005+A1:2012 
[27] Mahmud, E., E. Abdulahad, \& Z. Bonev, "Influence of masonry infill on the seismic behaviour of reinforced concrete frame structures," X Jubilee International Scientific Conference "Civil Engineering Design and Construction "(Science and Practice), pp. 622-632, 2018.

\section{ABSTRACT}

\section{NONLINEAR SEISMIC ANALYSIS OF MASONRY INFILLED RC FRAME STRUCTURES}

\section{Emin MAHMUD \\ Zdravko BONEV \\ Emad ABDULAHAD}

Structures composed of different substructures and materials are a subject of great research and expert interest. It is the purpose of this research to develop an engineering approach for evaluation of seismic demands and to apply the methodology to reinforced concrete frames with or without masonry infill. This paper deals with combination of reinforced concrete frame and masonry infill wall. It is known that the combined structure resists well to severe earthquakes. In this paper, the influence of masonry infill on the seismic demands of a reinforced concrete frame structure is estimated using nonlinear analysis. A strut model was used to model the masonry infill resistance; the strut model is statically equivalent to the masonry infill wall. Therefore, material properties of the strut element are determined based on material properties of continuous masonry wall and geometry data.

The seismic analysis is performed including material nonlinearity of the model. Determination of seismic displacement demands is carried out using an approximate procedure of the nonlinear analysis in N2method. To make evaluation of masonry contribution two varieties of the models have been studied - "with masonry infill" and "without masonry infill".

Key words: Masonry infill, nonlinear analysis, seismic action, seismic behaviour, N2-method, RC frame structure, response spectrum method
[28] Eurocode 8: Design of structures for earthquake resistance - Part 3: Assessment and retrofitting of buildings - National annex to BDS EN 1998-3:2005

[29] Fajfar, P. \& M. EERI, "A Nonlinear Analysis Method for Performance Based Seismic Design," Earthq. Spectra, vol. 16, no. 3, pp. 573-592, 2000.

\section{REZIME}

\section{NELINEARNA SEIZMIČKA ANALIZA AB OKVIRNIH KONSTRUKCIJA SA ZIDNOM ISPUNOM}

\section{Emin MAHMUD \\ Zdravko BONEV \\ Emad ABDULAHAD}

Konstrukcije sastavljene od različitih potkonstrukcija i materijala jesu tema brojnih istraživača i interesa stručnjaka. Svrha ovog rada jeste da se razvije inženjerski pristup za procenu seizmičkog odgovora i da se metodologija primeni na armiranobetonske (AB) okvire sa ispunom i bez ispune. Ovaj rad bavi se kombinacijom $A B$ okvira i zidane ispune. Poznato je da su kombinovane konstrukcije otporne na jake zemljotrese. U ovom radu uticaj zidane ispune na seizmički odgovor $A B$ okvira rešava se nelinearnom analizom. Metoda pritisnutog štapa primenjena je da bi se modelirao otpor zidane ispune, a metod pritisnutog štapa je statički ekvivalentan zidanoj ispuni. Dakle, materijalna svojstva pritisnutog štapa određena su na osnovu svojstava materijala zidane ispune i geometrijskih podataka.

Seizmička analiza sprovedena je uzimajući u obzir materijalnu nelinearnost modela. Određivanje pomeranja - kao seizmičkog odgovora - sprovedeno je približnom metodom nelinearne analize N2. Prednost ispune $u$ seizmičkom odgovoru ispoljava se smanjenjem pomeranja. Da bi se napravila procena uticaja ispune, analizirane su dve varijante modela - sa zidanom ispunom i bez zidane ispune. $U$ prvom slučaju, sračunat je uticaj zidane ispune. $U$ drugom slučaju, otpor zidane ispune nije uziman u obzir i nije uključena „pomoć” zidarije.

Ključne reči: zidana ispuna, nelinearna analiza, seizmičko dejstvo, seizmičko ponašanje, $N 2$ metoda, $A B$ okvirne konstrukcije, metod spektra odgovora 